\title{
Nutritional Status in Apples and June Drop
}

\author{
Alessandro Abruzzese', Ilaria Mignani ${ }^{2}$, and Sergio M. Cocucci ${ }^{1}$ \\ Facoltà di Agraria, Università degli Studi di Milano, Via Celoria 2, 20133 Milan, Italy
}

Additional index words. Malus domestica

\begin{abstract}
Apple (Malus domestica Borkh.) trees are often affected by a severe June fruit drop, which is often correlated with competition phenomena involving fruit nutrition. This research was initiated to determine if June drop in 'Gloster'/ M.9 apple could be correlated with a diminished nutrient availability in developing seeds and fruit. During the test period [30 to 62 days after full bloom (AFB)], the fruit that abscised had a diameter similar to that reached by persisting fruit 13 days earlier. Biochemical parameters related to nutritional status of fruit were measured when an abscission peak occurred 38 days AFB. Persisting fruit (control) and abscised fruit were compared along with fruit that abscise 13 days later. The cortex tissue obtained from the two kinds of abscised fruit showed a higher level of soluble reducing sugars and sucrose and a lower content of $\mathrm{K}^{+}$, acid hydrolyzable polysaccharides, and protein compared to the control. Further, the $\mathrm{Ca}^{2+}$ content was higher in abscised fruit than in controls of the same age, whereas there was no difference when fruit of the same size were compared. Total amino acid level was similar in control and abscised fruit at the same age, but there was a lower amino acid level in abscised fruit of the same size. Histological analysis of cortex tissue indicated that abscised fruit have larger cells with less evident nuclei and thinner cell walls than controls. Compared to control fruit, abscised fruit showed the same average number of seeds and a severe inhibition of seed growth; seeds from both kinds of abscised fruit had the same or higher levels of the parameters measured. No positive correlations were observed between fruit abscission and nutrient content of seeds or fruit.
\end{abstract}

It would be useful to understand the mechanism underlying fruit persistence and abscission. After many years of investigation of apple abscission, hormone and nutritional factors have been suggested as abscission-controlling factors. Many studies have elucidated aspects of fruit abscission, including the descriptive work reported by Heinicke (1919), with anatomical and morphological structure of the developing fruit and the abscission layers reported later (Avanzi et al., 1986; McCown, 1943; McDaniels, 1937; Murneek, 1954; Smith, 1940; Tukey and Young, 1942). Competition among fruit of different sizes or positions on the limb and among different vegetative organs has been investigated (Beruter and Droz, 1991; Poma Treccani et al., 1982; Westwood et al., 1967) to determine the nutritional factors affecting "June drop" (Liu et al., 1990; Rizzi and Abruzzese, 1988) as related to carbohydrate transport, mineral translocation, protein synthesis, number of seeds or developed embryo per seed, and climatic conditions (Avanzi et al., 1988; Byers et al., 1991; Forino et al., 1987; Saito et al., 1989).

Plant hormone levels have been implicated in abscission processes since 1948 when Luckwill (1948) reported that auxin-like hormones decreased in abscising apples. The hormone balance of developing fruit (Trehame et al., 1985) and hormone synthesis in growing seeds are widely studied as related to fruit abscission (Avanzi et al., 1986, 1988; Fukui, 1990). These and other studies on hormones leave unanswered the many questions about the mechanism of abscission.

To evaluate if June drop can be associated with lack of nutrient availability, the work described herein examined the 1) growth in persisting and abscised fruit, 2) time course of abscission, 3) seed number, 4) level of nutrients in seeds and cortex tissue of fruit, and 5) cell size and the status of the cell wall in the cortical region in abscised and persisting fruit.

Received for publication 27 Dec. 1993. Accepted for publication 16 May 1994. Research supported by M.U.R.S.T 40\%. We are deeply indebted to George Martin for reading the manuscript. We also remember with gratitude the contribution of Cesarina Poma Treccani (deceased) in planning the experiment. The cost of publishing this paper was defrayed in part by the payment of page charges. Under postal regulations, this paper therefore must be hereby marked advertisement solely to indicate this fact.

'Dipartimento di Fisiologia delle Piante Coltivate e Chimica Agraria.

${ }^{2}$ Istituto di Coltivazioni Arboree.

\section{Materials and Methods}

Plant material. Six-year-old 'Gloster' apple trees on M.9 rootstock, grown on the experimental farm of the Univ. of Milan (Northern Italy) at Montanaso Lombardo, were used with three experimental blocks of three trees each. Full bloom was on 16 Apr.

To collect and count the daily abscised fruit, a net was placed under each plant and the number of abscised fruit was recorded between 30 and 62 days after full bloom (AFB). The fruit that abscised in the night were counted but not sampled. The fruit that abscised during the day were collected each hour, between 9 AM to $6 \mathrm{PM}$, the pedicel was removed, and the fruit were randomized and stored at 2 to $4 \mathrm{C}$. At the end of the sampling time, 30 fruit were weighed and their equatorial diameter was measured. During the same period, the diameter of 30 persisting fruit, without any early sign of abscission (reddening of the pedicel), was measured.

A peak of abscission was recorded 38 days AFB. For chemical measurements, a sample of 30 abscised and 30 persisting fruit, without any early sign of abscission, was collected. The cortex tissue was sampled, cut into small pieces, and randomized. The seeds from each fruit were collected, counted, weighed, and randomized. After separation into various components, all plant material was frozen in liquid $\mathrm{N}$ and stored at $-80 \mathrm{C}$.

Because the abscised fruit reached the same diameter of persisting fruit 13 days later, abscised fruit were sampled 51 days after full bloom, as indicated above, to compare the considered parameters in persisting vs. abscised fruit with the same diameter.

Concentration of reducing sugars, sucrose, acid hydrolyzable polysaccharides, amino acids, andprotein in apple cortex tissue and in apple seeds. The apple cortex tissue was fractionated according to the method of Nieman and Poulsen (1963). Two grams of a randomized sample of apple cortex tissue was homogenized in $8 \mathrm{ml}$ of $10 \%(\mathrm{v} / \mathrm{v})$ ice-cold perchloric acid (PCA); the homogenate was centrifuged at $2 \mathrm{C}(10 \mathrm{~min}$ at $13,000 \times \mathrm{g})$, and the pellet was washed with $2 \mathrm{ml}$ of PCA and recentrifuged. A part of the total collected supernatant (acid soluble fraction) was adjusted to $\mathrm{pH} 7$ with $\mathrm{K}_{2} \mathrm{CO}_{3}$ to remove PCA (Hohorst, 1963). After centrifugation $(10 \mathrm{~mm}$ at $13,000 \times \mathrm{g})$, aliquots of this neutralized supernatant were used to assay reducing sugars by the calorimetric method of Nelson (1944) and amino acids by the ninhydrin method 
(Moore and Stein, 1954). The data are expressed as $\mu$ mol glucose and $\mu$ mol leucine/g fresh weight.

Total soluble sugars were determined according to Nelson's (1944) method on a fraction of acid supernatant after hydrolysis for $1 \mathrm{~h}$ at $90 \mathrm{C}$, neutralization by $\mathrm{K}_{2} \mathrm{CO}_{3}$, and centrifugation ( $10 \mathrm{~min}$ at $13,000 \times \mathrm{g})$. Sucrose content was calculated as the difference between the amount of total soluble sugars and reducing sugars and expressed as $\mu \mathrm{mol}$ sucrose/g fresh weight.

The acid insoluble fraction was resuspended in $2 \mathrm{~N}_{2} \mathrm{SO}_{4}$ and heated at $90 \mathrm{C}$ for $2 \mathrm{~h}$. After hydrolysis, the soluble fraction was collected by centrifugation ( $10 \mathrm{~min}$ at $13,000 \times \mathrm{g}$ at $4 \mathrm{C}$ ), neutralized by $\mathrm{NaOH}$, and used to determine the acid hydrolyzable polysaccharides by Nelson's (1944) method. The data are expressed as $\mu \mathrm{mol}$ glucose/g fresh weight. The pellet was resolubilized by $1 \mathrm{~N}$ $\mathrm{NaOH}$ overnight and recentrifuged to collect the soluble fraction used to determine the alkali soluble protein content with the BioRad protein assay method (Bradford, 1976). The data are expressed as $\mathrm{mg}$ protein/g fresh weight.

After randomization, apple seeds were processed as described above for cortex tissue of the fruit.

All described fractionations and analyses were carried out in triplicate.

Calcium and potassium levels in the fruit. The $\mathrm{Ca}^{2+}$ and $\mathrm{K}^{+}$ contents of cortex and seeds were measured after mineralizing samples by wet digestion (Lamiani Mignani et al., 1983). Two and one-half milliliters of triacid mix (15 nitric acid : 1 sulphuric acid $: 1$ perchloric acid) was added to $0.5 \mathrm{~g}$ of apple cortex tissue and thermoregulated at $240 \mathrm{C}$ until the samples were clear. The wet digestion was performed in triplicate.

The cation levels were measured by an atomic absorption spectrophotometer (Techtron AA475; Varian, Mulgrove, Victoria, Australia) and expressed as $\mu \mathrm{mol} / \mathrm{g}$ fresh weight.

Optical microscope analysis of apple cortex tissue. Apple cortex samples were cut in small pieces and immediately fixed in formalin acetic acid alcohol. After hydration in a graded series of ethyl alcohol and propylene oxide, the probes were imbedded in Paraplast (Sherwood, St. Louis), sectioned by microtome, stained with fucsin (Shiff's reagent), and examined by microscope.

\section{Results}

Most fruit abscission occurred between 32 and 39 days AFB, with two abscission peaks at 34 and 38 days AFB (Fig. 1a). Abscission gradually diminished after 45 days AFB. The statistical analysis of the average number of abscised fruit per tree indicate that the coefficient of variation was not higher than $9 \%$ during the test period (data not shown). During the test period, the growth (as diameter) of the fruit that abscised was lower than that of persisting fruits. Growth of abscised fruit lagged -13 days behind that of persisting fruit (Fig. 1b).

At 38 days AFB, the average fresh weight of abscised fruit was $56 \%$ lower than that of persisting fruits, whereas the fresh weight of the fruit that abscised 13 days later was similar to persisting fruit (Table 1). The average number of seeds was the same in abscised and persisting fruit. The average seed weight from abscised fruit was lower than that from persisting fruit. Seed weights of abscised fruit of the same age and same size were 55\% and 47\% lower, respectively, than the seed weights of persisting fruit.

Seeds from persisting and abscised fruit of the same age and the size did not differ significantly in the content of soluble reducing sugars, amino acids, and protein. In contrast, the contents of $\mathrm{K}^{+}$, $\mathrm{Ca}^{2+}$, and sucrose were greater in seeds from abscised than persisting fruit (Table 2).

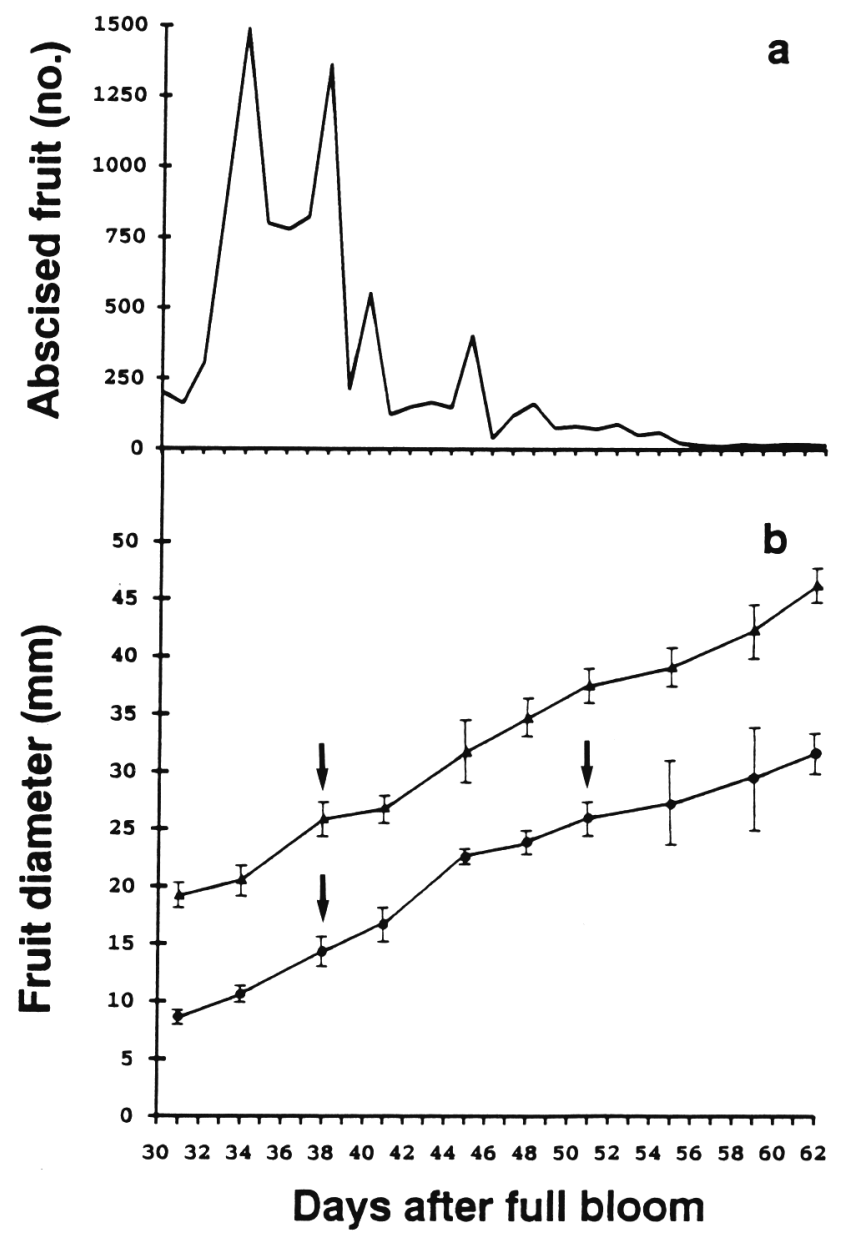

Fig. 1. Total abscised apples per day from 30 to 62 days after full bloom (a) and fruit growth (as average equatorial diameter) of persisting apples (control, $\boldsymbol{\Delta}$ ) and abscised apples ( $)$ during the same period (b). Bars indicate $\pm \mathrm{SD}$, and the arrows indicate the sampling days for chemical analyses.

Table 1. Average fruit weight and number of seeds and seed weight of persisting apples 38 days after full bloom (control) and abscised apples at the same age and later when abscised fruit were at the same size as the control, 38 and 51 days after full bloom, respectively $( \pm \mathrm{SE})$.

\begin{tabular}{lccc}
\hline & \multirow{2}{*}{$\begin{array}{c}\text { Fruit } \\
\text { fresh wt }\end{array}$} & \multicolumn{2}{c}{ Seed } \\
\cline { 3 - 4 } Fruit & $(\mathrm{g})$ & No. & Fresh wt $(\mathrm{mg})$ \\
\hline $\begin{array}{l}\text { Control } \\
\begin{array}{c}\text { Abscised } \\
\text { (same age) }\end{array}\end{array}$ & $9.1 \pm 0.13$ & $6.5 \pm 0.15$ & $13.4 \pm 0.43$ \\
$\begin{array}{c}\text { Abscised } \\
\text { (same size) }\end{array}$ & $4.0 \pm 0.08$ & $6.3 \pm 0.21$ & $6.3 \pm 0.18$ \\
\hline
\end{tabular}

In the cortex tissue of fruit, concentrations of soluble reducing sugars and sucrose were greater in abscised than in persisting fruit (Table 3). Calcium concentration was greater in abscised fruit the same age as persisting fruit, yet both were similar when compared at the same size. Potassium, acid hydrolyzable polysaccharides, and protein concentrations were lower in both kinds of abscised fruit compared to persisting fruit. Total amino acids were similar in persisting and abscised fruit of the same age. However, there was a reduction in the concentration of total amino acids in abscised fruit compared to persisting fruit of the same size. 


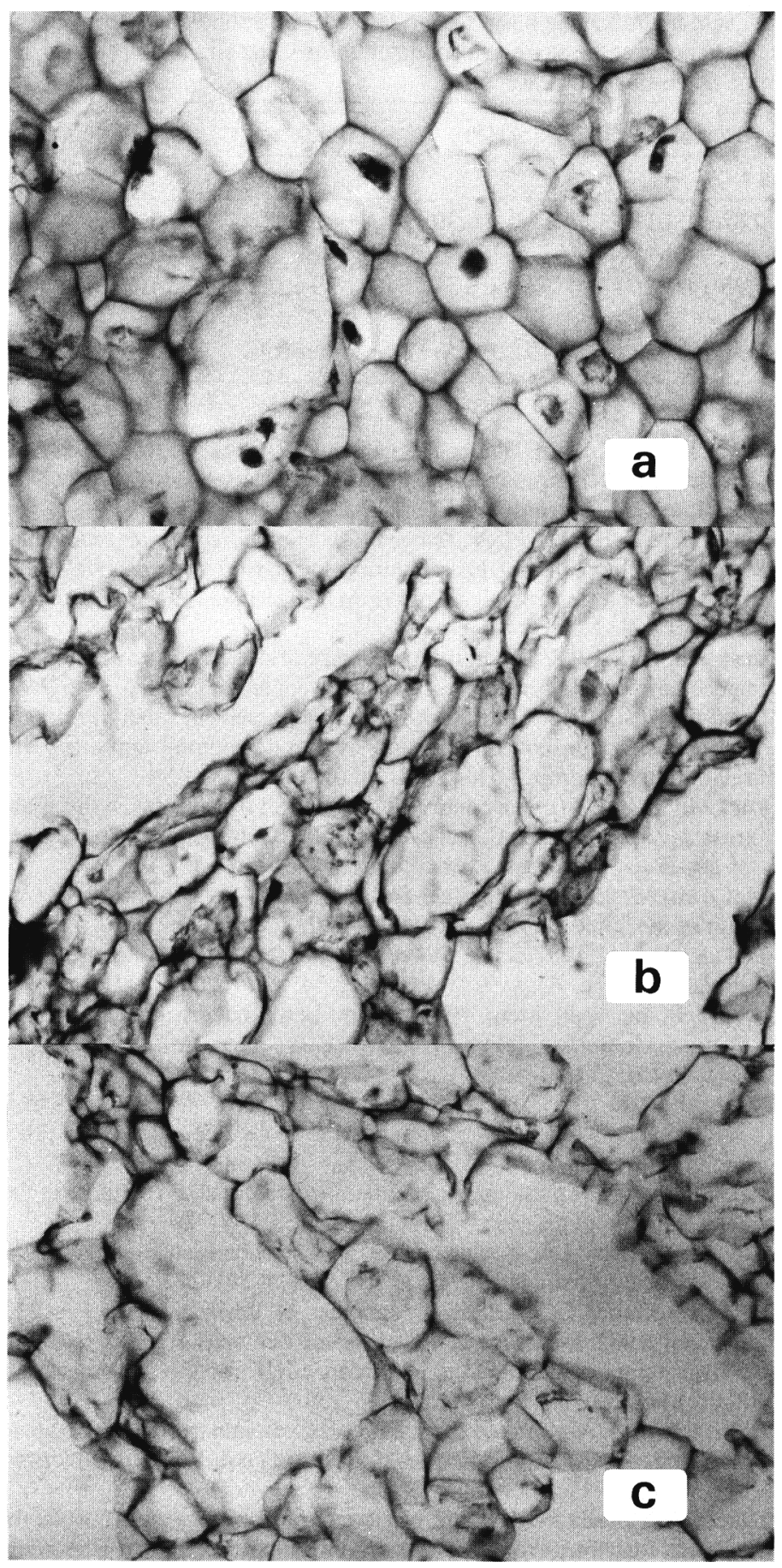

Fig. 2. Microphotographs of apple cortex tissue at different stages of development: (a) persisting fruit 38 days after full bloom; (b) abscised fruit 38 days after full bloom; (c) abscised fruit 51 days after full bloom.
The histological analysis performed on cortical tissue of fruit showed that abscised fruit have, with respect to persisting fruit, larger cells, with less-evident nuclei and thinner cell walls (cell walls easily broke during preparation) (Fig. 2).

\section{Discussion}

Starting at full bloom, competition for nutrients among flowers and eventually between fruit and vegetative organs takes place. Others reported that nutrient competition causes fruit abscission in apple (Abbott, 1960; Luckwill, 1970) and Pisum (Carbonell and Garcia-Martinez, 1980). In the early fruit growth period, seed development also plays an important role in determining fruit abscission, as seed tissues are implicated in hormone synthesis (Luckwill, 1948, 1953).

Under the climatic conditions of Northern Italy, there normally is more than one peak in apple abscission (Fig. la); in the present case, two abscission peaks occurred within a very short time. This behavior did not depend on particular climatic events, such as strong wind or hail, but occurred as a consequence of some unknown.

In our experimental conditions, fruit that abscised had the same fertilization as persisting fruit (as indicated by the number of seeds) but exhibited slower growth, reaching the same diameter only 13 days later. Seeds from the abscised fruit showed severe growth inhibition that was not restored with time. Even so, the fruit that abscised did not show a reduction in the availability of substances analyzed in the seeds such as $\mathrm{K}^{+}$and $\mathrm{Ca}^{2+}$. In fact, sucrose content was even higher in abscised than in persisting fruit. The growth inhibition of fruit that abscised was accompanied in the cortex tissue by a decrease in $\mathrm{K}^{+}$, protein, and acid hydrolyzable polysaccharides and, with time, by a decrease in amino acids, whereas sucrose and $\mathrm{Ca}^{2+}$ were at greater concentrations than in persisting fruit.

These differences are in part confirmed by the histological analysis of the cortex tissue of fruit (Fig. 2). The micrographs showed an increase in cell distension, a reduction in cell division, a lower development of the wall of the cells, and a lower activity of the nuclei in abscised fruit.

A decrease of total amino acids in abscised fruit suggests that the growth of seeds and fruit could be related to a lower content of some specific amino acids with a negative effect on protein synthesis and growth. Our preliminary analyses (data not shown) revealed a reduction in the content of total amino acids in abscised fruit, which appears to be correlated to a reduction in the content of the amino acids linked to the mobilization of nitrogenous compounds (Tromp and Ovaa, 1971, 1973). Greater concentrations of other nutrients in abscised fruit may be due to a reduction in their use.

Abscised fruit might be in an extreme physiological condition that does not represent the physiological condition of abscission.

Table 2. Concentrations of $\mathrm{K}^{+}, \mathrm{Ca}^{2+}$, soluble reducing sugars (SRSs), sucrose, amino acids, and protein in seeds of persisting apples 38 days after full bloom (control) and abscised apples at the same age and later at the same size as the control, 38 and 51 days after full bloom, respectively. The values are the means of nine determinations \pm SE.

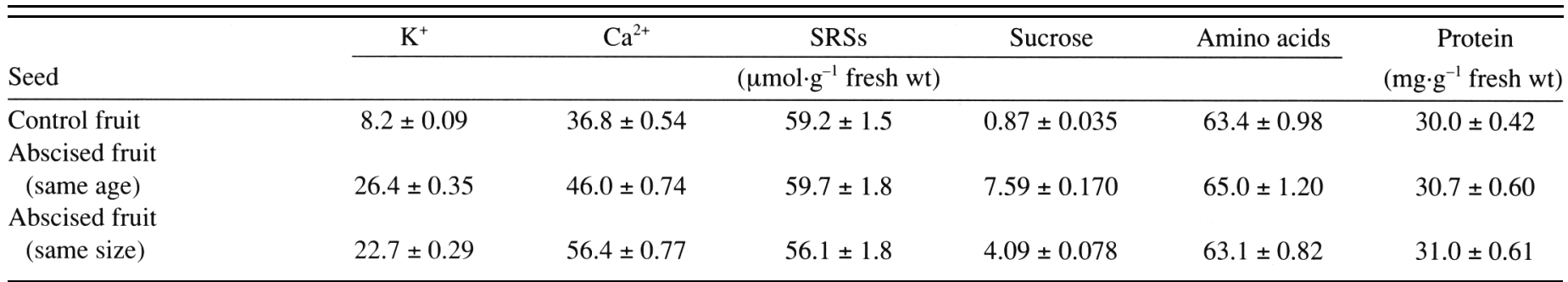


Table 3. Concentrations of $\mathrm{K}^{+}, \mathrm{Ca}^{2+}$, soluble reducing sugars (SRSs), sucrose, acid hydrolyzable polysaccharides (AHPs), amino acids, and protein in cortex tissue from persisting apples at 38 days AFB (control) and abscised apples at the same age and later at the same size as the control, 38 and 51 days after full bloom, respectively. The values are the means of nine determinations $\pm \mathrm{SE}$.

\begin{tabular}{|c|c|c|c|c|c|c|c|}
\hline \multirow[b]{2}{*}{ Fruit } & $\mathrm{K}^{+}$ & $\mathrm{Ca}^{2+}$ & SRSs & Sucrose & AHPs & Amino acids & \multirow{2}{*}{$\begin{array}{c}\text { Protein } \\
\left(\mathrm{mg} \cdot \mathrm{g}^{-1} \text { fresh } w t\right)\end{array}$} \\
\hline & \multicolumn{6}{|c|}{$\left(\mu \mathrm{mol} \cdot \mathrm{g}^{-1}\right.$ fresh wt $)$} & \\
\hline Control & $44.1 \pm 0.69$ & $3.5 \pm 0.070$ & $91.0 \pm 1.2$ & $0.87 \pm 0.011$ & $71.0 \pm 0.99$ & $14.2 \pm 0.26$ & $3.5 \pm 0.045$ \\
\hline $\begin{array}{l}\text { Abscised } \\
\text { (same age) }\end{array}$ & $29.3 \pm 0.44$ & $6.5 \pm 0.070$ & $109.9 \pm 1.4$ & $1.75 \pm 0.026$ & $39.9 \pm 0.53$ & $13.9 \pm 0.25$ & $1.9 \pm 0.027$ \\
\hline $\begin{array}{l}\text { Abscised } \\
\text { (same size) }\end{array}$ & $28.0 \pm 0.46$ & $3.6 \pm 0.061$ & $101.6 \pm 1.3$ & $1.46 \pm 0.022$ & $43.8 \pm 0.58$ & $9.8 \pm 0.14$ & $2.8 \pm 0.035$ \\
\hline
\end{tabular}

On the other hand, we encountered the same difficulties in characterizing the signs of future abscission. This was only linked to a specific reddening of the pedicel and to easier dropping of the fruit as a consequence of a slight shaking of the branch. Sampling fruit with these characteristics 38 days AFB and that were destined to abscise later confirmed that the growth level (as diameter) and nutritional parameters considered were at intermediate levels between persisting and abscised fruit at the same date (data not shown).

The present data suggest that fruit abscission was not linked to a nutrient deficiency. In fact, nutrient levels remained high and the related metabolism seems to persist in fruit that abscise. The presence of the same number of seeds (i.e., a tissue that produces hormones) tends to exclude the possibility of hormone deficiency as a causal factor in abscission.

We will evaluate the difference of hormonal content in persisting and abscised fruit to better elucidate this point.

\section{Literature Cited}

Abbott, D.L. 1960. The bourse shoot as a factor in the growth of apple fruitlets. Ann. Applied Biol. Rpt. Long Ashton Res. Sta. 48:434-438.

Avanzi, S., L.M.C. Forino, A.M. Tagliasacchi, N. Ceccarelli, R. Lorenzi, P. Vernieri, and R. Bonomo. 1986. Malus domestica Borkh: Histological structure and gibberellin activity of ovules of control and of "June drop" affected fruit. Acta Hort. 179:275-276.

Avanzi, S., P. Vernieri, N. Ceccarelli, A.M. Tagliasacchi, L.M.C. Forino, R. Lorenzi, and R. Bonomo. 1988. Developmental stages and gibberellin activity in ovules of abscission affected fruit of Malus domestica Borkh. J. Plant Physiol. 132:10-15.

Beruter, J. and P. Droz. 1991. Studies on locating the signal for fruit abscission in apple tree. Scientia Hort. 46:201-214.

Bradford, M.M. 1976. A rapid and sensitive method for the quantitation of protein utilizing the principle of protein dye binding. Anal. Biochem. 72:248-254.

Byers, R.E., D.H. Carbaugh, C.N. Presley, and T.K. Wolf. 1991. The influence of low light on apple fruit abscission. J. Hort. Sci. 66:7-17.

Carbonell, J. and J.L. Garcia-Martinez. 1980. Fruit-set of unpollinated ovaries of Pisum sativum L. Influence of vegetative parts. Planta 147:444-450.

Forino, L.M.C., A.M. Tagliasacchi, and S. Avanzi. 1987. Embryo-sacs frequency in ovules of abscission affected fruit in Malus domestica Borkh. Adv. Hort. Sci. 1:65-67.

Fukui, H., S. Imakova, and I. Tamura. 1990. Investigation on the factors of in vitro embryo development in relation to early fruit drop in apple. Memoirs Faculty Agr., Hokkaido Univ. 17:18-24.

Heinicke, A.J. 1919. Concerning the shedding flowers and fruits and other abscission phenomena in apples and pears. Proc. Amer. Soc. Hort. Sci. 16:76-83.

Hohorst, H.I. 1963. Malate determination with malic dehydrogenase and DPN, p. 328-332. In: H.U. Bergmeyer (ed.). Method of enzymatic analysis. Verlag-Chemie, Weinheim.
Lamiani Mignani, I., C. Poma Treccani, and S. Cocucci. 1983. Bitter-pit incidence and changes in $\mathrm{Ca}^{2+}$ content in apple after post-harvest dip in $\mathrm{CaCl}_{2}$ or GA,. Scientia Hort. 19:295-299.

Liu, X.Z., S.J. Hsu, and L.Y. Jiang. 1990. The fluctuation in protein and amino acid contents of leaves during the spring flush in relation to flowering and physiological fruit drop in Valencia orange. Acta Hort. Sinica 17:21-28.

Luckwill, L.C. 1948. The hormone content of the seed in relation to the endosperm development and fruit drop in apple. J. Hort. Sci. 24:32-44.

Luckwill, L.C. 1953. Studies on fruit development in relation to plant hormones. I. Hormone production by the developing apple seed in relation to fruit drop. J. Hort. Sci. 28: 14-24.

Luckwill, L.C. 1970. The control of growth and fruitfulness in the apple trees, p. 232-254. In: L.C. Luckwill and C.V. Cutting (eds.). Physiology of tree crops. Academic Press, London.

McCown, M. 1943. Anatomical and chemical aspects of abscission of fruit of the apple. Bot. Gaz. 105:212-220.

McDaniels, L.H. 1937. Some anatomical aspects of apple flower and fruit abscission. Proc. Amer. Soc. Hort. Sci. 34: 122-129.

Moore, S. and W.H. Stein. 1954. A modified ninhydrin-reagent for the photometric determination of amino acids and related compound. J. Biol. Chem. 211:907-926.

Murneek, A.E. 1954. The embryo and endosperm in relation to fruit development, with special reference to the apple, Malus silvestris. Proc. Amer. Soc. Hort. Sci. 64:573-582.

Nelson, N. 1944. A photometric adaptation of the Somogyi method for the determination of glucose. J. Biol. Chem. 153:375-380.

Nieman, R.H. and L.L. Poulsen. 1963. Spectrophotometric estimation of nucleic acid of plant leaves. Plant Physiol. 18:240-244.

Poma Treccani, C., C. Bellini, F. Malandra, B. Varisco, C. Visai, and F. Zucconi. 1982. Dinamica dell'abscissione dei frutti di melo: relazioni con lo sviluppo della lamburda, delle frecce e del frutto. Riv. Ortoflorofrutt. It. 66:147-159.

Rizzi, E. and A. Abruzzese. 1988. Effects of calcium treatments on some biochemical indices during the development of apple fruit. Agr. Mediterr. 118:311-318

Saito, S., I. Tamada, H. Ichinohe, N. Obara, andT. Mikami. 1989. Relation between early fruit drop in apple trees and climatic factors. Bul. Aomori Apple Expt. Sta. 25:73-86.

Smith, W.H. 1940. The histological structure of the flesh of the apple in relation to growth and senescence. J. Pomol. Hort. Sci. 18:249-260.

Trehame, K.J., J.D. Quinlan, J.N. Knight, and D.A. Ward. 1985. Hormonal regulation of fruit development in apple: A mini-review. Plant Growth Regulat. 3:125-132.

Tromp, J. and J.C. Ovaa. 1971. Spring mobilization of storage nitrogen in isolated shoot sections of apple. Physiol. Plant. 25:16-22.

Tromp, J. and J.C. Ovaa. 1973. Spring mobilization of protein nitrogen in apple bark. Physiol. Plant. 29:1-5.

Tukey, H.B. and J.O. Young. 1942. Gross morphology and histology of developing fruit of the apple. Bot. Gaz. 104:3-25.

Westwood, M.N., L.P. Batjer, and H.D. Billingsley. 1967. Cell size, cell number and fruit density of apples as related to fruit size, position in cluster and thinning methods. Proc. Amer. Soc. Hort. Sci. 91:51-62. 